\title{
Outcome Expectations and Social Entrepreneurial Intention: Integration of Planned Behavior and Social Cognitive Career Theory*
}

\author{
Phan Tan LUC ${ }^{1}$
}

Received: March 17, 2020 Revised: April 04, 2020 Accepted: May 01, 2020

\begin{abstract}
The paper examines social entrepreneurial intention through outcome expectations. The proposed model incorporates outcome expectations from social cognitive career theory and theory of planned behaviors. The study also introduces a scale for outcome expectations in social entrepreneurship, including solving social problems, innovation, family tradition of social involvement, meaning in life, prestige and social recognition, competitive and favorite job and wealth. A survey of 279 students was conducted through face-to-face structured interviews. The confirm factor analysis and technique of structural equation modeling were used to explore relationships among latent constructs. Research results show that the outcomes impact only through three determinants of theory of planned behavior and do not have significant impact to social entrepreneurial intention. It suggests that outcome expectations may be a flexible factor. Individual outcome expectations can shift to motivations when facing favorable conditions such as family support, government support, etc. The findings suggest that the ability to predict social entrepreneurial intention of attitude toward behavior, subjective norms, and perceived behavioral control. The proposed model in this study contributes importantly to the emerging literature on entrepreneurial intention, particularly to social entrepreneurial intention. This study is also the first quantitative study to measure the impact of outcome expectations on social entrepreneurial intention.
\end{abstract}

Keywords : Outcome Expectations, Social Entrepreneurial Intention, Social Entrepreneurship.

JEL Classification Code: D9, L26, L31.

\section{Introduction}

Social issues are becoming more diversified and complex such as poverty, climate change, unemployment and so on. These are indeed real obstacles for governments to strive for the sustainable development of society. Social enterprise is considered as a solution to assist governments in addressing social issues effectively because social enterprises have both economic and non-economic objectives (Seelos, 2014). Despite the efficiency that social enterprises have brought as well as the very large potential of this type of enterprise,

\footnotetext{
"This research is funded by Thu Dau Mot University

${ }^{1}$ First Author and Corresponding Author. Department of Economics, Faculty of Economics, Thu Dau Mot University, Vietnam [Postal Address: 8 Tran Van On Street, Phu Hoa Ward, Thu Dau Mot City, Binh Duong, 590000 Vietnam] E-mail: lucpt@tdmu.edu.vn

(c) Copyright: The Author(s)

This is an Open Access article distributed under the terms of the Creative Commons Attribution Non-Commercial License (http://Creativecommons.org/licenses/by-nc/4.0/) which permits unrestricted noncommercial use, distribution, and reproduction in any medium, provided the original work is properly cited.
}

the number of social enterprises in developing countries is still very low (Phan, 2018). Intention is the best indicator for behavior (Ajzen, 1991, 2002), and entrepreneurial intention arguably plays an important role in the decision to create a business (Liñán \& Chen, 2009). Therefore, one of the ways to increase the number of social enterprises as well as social entrepreneurs is to understand the process of forming social entrepreneurial intention.

Outcome expectations are considered as one of the main factors affecting entrepreneurial intention in general and social entrepreneurial intention in particular (Jiang \& Wang, 2014; Lanero et al., 2016; Liguori et al., 2018; Manolova et al., 2008; Shaw \& Carter, 2007). Commercial enterprises operate for profit while social enterprises operate for the purposes of meeting the needs of society, so the outcome expectations of social entrepreneur are completely different from those of commercial entrepreneurs (Aileen Boluk \& Mottiar, 2014; Austin et al., 2006; Germak \& Robinson, 2014; Mair \& Marti, 2006; Zahra et al., 2009). Although outcomes expectations been mentioned by many researchers, these studies are only qualitative studies in entrepreneurship.

To provide a deeper understanding of the outcome expectations in social entrepreneurship, the author conducted 
a quantitative study to develop a scale for outcome expectations base on Schwartz (1992) theory of values, and examined the relationship between expectations and social entrepreneurial intention. This paper draws two theory regarding intention: (1) the theory of planned behavior (TPB) (Ajzen, 1991), and (2) social cognitive career theory (SCCT) (Lent et al., 1994, 2000). TPB has been widely used in many studies of entrepreneurial intention in general and social entrepreneurial intentions in particular (Do Paco et al., 2011; Grünhagen \& Volkmann, 2014; Iakovleva \& Solesvik, 2014; Vikstrom \& Westerberg, 2010; Zainuddin \& Ismail, 2011). SCCT is a new approach to measure social entrepreneurial intention (Lanero et al., 2016; Tran et al., 2016) and this approach has not been fully researched. Furthermore, outcome expectations are known as important factor in SCCT. Therefore, TPB and SCCT are the most appropriate tools for understanding the outcome expectations of social entrepreneurial intention. This study integrated outcome expectations in SCCT into TPB to measure social entrepreneurial intention and then examined the direct and indirect effects of outcome expectations on social entrepreneurial intention. The integrated model and scale of outcome expectations are considered as contributions to social entrepreneurship literature.

The purposes of this study are as follows:

1. To develop scale for outcome expectations.

2. To investigate the effect of outcome expectations on social entrepreneurial intention and determinants of TPB.

This paper starts with the introduction of two theories: social cognitive career theory and theory of planned behavior. Next, research model and hypotheses are reported. The following section presents results and discussion. The limitations, future research and conclusions comprise the final section of this paper.

\section{Theoretical Background}

\subsection{Social Entrepreneurial Intention}

Bird (1988) defined intention as a state of mind that motivates a person towards a specific goal. Intention can be considered a prerequisite for behavior (Lu \& Wang, 2018; Tran, 2020). According to Krueger and Brazeal (1994), entrepreneurial intention can be defined as a personal commitment to starting an enterprise in the future. Thus, entrepreneurial intention is an indispensable trend for the establishment of new businesses. Entrepreneurial intention can help understand why entrepreneurs plan to start a business. The social entrepreneurial intention in this study is defined as the belief and self-recognition of a person who intends to establish a new social venture (Ip et al., 2017).

\subsection{Social Cognitive Career Theory (SCCT)}

Social cognitive career theory was developed from Bandura's social cognitive theory (Bandura, 1982). SCCT is widely used to explain decision-making behavior related to occupational issues. This theory suggests that the intention to perform an individual behavior is influenced by cognitive factors including self-efficacy and outcome expectations. Self-efficacy is an individual assessment capacity to organize and carry out his/her own actions to achieve goals ("I know I can do it"). Outcome expectations are the individual belief in the outcome that the action will bring.

Self-efficacy. Self-efficacy refers to "people's beliefs about their capabilities to exercise control over their own level of functioning and over events that affect their lives" (Bandura, 1993). Self-efficacy includes two conceptualizations: domain specific self-efficacy (Arenius \& Minniti, 2005; Zhao et al., 2005) and generalized selfefficacy (Bandura, 1982). SCCT considers that generalized self-efficacy and self-efficacy are generalized dynamics core components of cognition. SCCT develops self-efficacy into four mechanisms: mastering experience, indirect experience, social persuasion, and physiological factors (Bandura, 1991; Wood \& Bandura, 1989).

Outcome expectations. Outcome expectations are beliefs about the consequences of behavior (Lent \& Brown, 2008). The outcomes expectations depend on experience, selfefficacy beliefs, and quality of one's ability (Liguori et al., 2018). The SCCT assumption is an individual who wishes and intends to perform a behavior when outcomes are more positive and in turn do not intend to when outcome expectations are more negative (Kahneman, 2003; Liguori et al., 2018).

\subsection{Theory of Planned Behavior (TPB)}

In 1991, Ajzen developed the theory of planned behavior (TPB). TBP was based on the premise that all behaviors require a certain planning. The three determinants of this theory included attitudes toward the behavior (ATB), subjective norms (SN), and perceived behavioral control (PBC). The TPB is designed to predict and explain human behavior in specific contexts. ATB refers to the extent to which individuals have favorable or unfavorable attitudes about the results that the behavior brings (Ajzen, 1991). ATB is considered the most important factor and has the strongest impact on intention (Koçoğlu \& Hassan, 2013). SN refer to the social pressure to perform or not to perform an act (Ajzen, 1991). SN consists of two components: normative beliefs and the motivation to comply with these beliefs. Depending on the social environment, these pressures may become a trigger for, or a barrier to, the development of a business career. PBC refers to individual's perceived sense 
of ability to perform a particular behavior (Ajzen, 1991). High levels of PBC increase the effort, persistence, and intention to perform behavior (Ajzen, 2002).

\section{Research Model and Hypothesis}

\subsection{Research Model}

The author used TPB and SCCT to model the formation of social entrepreneurial intention. This study selects the determinants of TPB as the mediator variables that affect social entrepreneurial intention. TPB explains entrepreneurial intention more consistently than other models (Iakovleva \& Solesvik, 2014; Moriano et al., 2012). Unlike other models, TPB provides a theoretical framework that can be used to measure wider range of intention and allows us to understand entrepreneurial intention without personal factors and social factors (Armitage \& Conner, 2001; Krueger et al., 2000). Although SCCT was introduced for the first time in career choice research, many studies have shown that SCCT has an impact on entrepreneurial intention (Liguori et al., 2018; Tran et al., 2016). SCCT considers outcome expectations - a factor that TPB has not explained yet when explaining the process of forming a business intention. Thus, in this study, the author integrates the outcome expectations in SCCT into Ajzen's (1991) TPB and examines the direct impact on the social entrepreneurial intention and the factors in TPB

On the other hand, it can be seen that perceived behavioral control in TPB and self-efficacy in SCCT are quite similar. Both are interested in perceived ability to perform a behavior (Ajzen, 2002). However, PBC is considered to be a broader concept than self-efficacy. Ajzen (2002) stated that selfefficacy and controllability are two components of PBC. Some studies have shown similar results (Iakovleva \& Solesvik, 2014). Therefore, in this study author only consider PBC in the research model (see Figure 1).

\subsection{Hypothesis Development}

Based on the proposed research model, the author proposed hypotheses. First, the hypotheses of TBP and SCCT are examined. Hypotheses 1,2 and 3 are proposed based on TPB, while hypothesis 4 is based on SCCT:

H1: Attitude towards behavior is positively associated with the social entrepreneurial intention.

H2: Subjective norm is positively associated with the social entrepreneurial intention.

H3: Perceived behavior control is positively associated with the social entrepreneurial intention.

H4: Outcome expectations are positively associated with social entrepreneurial intention.

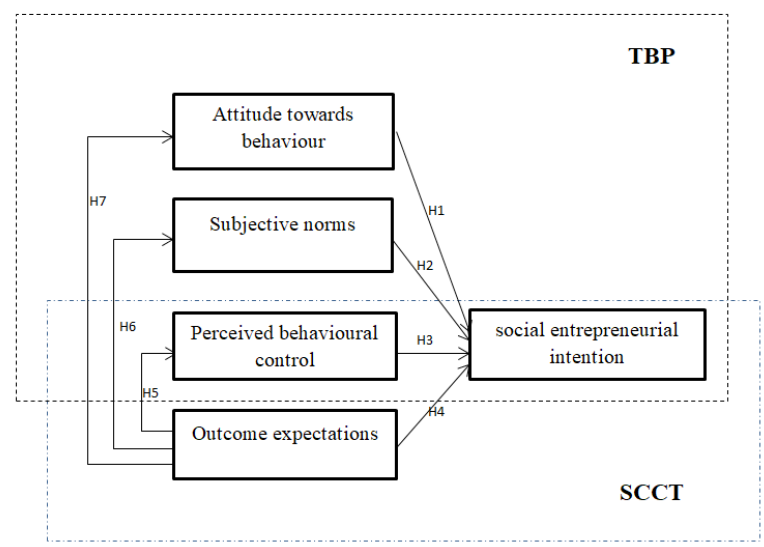

Figure 1. The proposed research model

In addition, the author examines the impact of outcome expectations on three determinants of Ajzen's (1991) theory of planned behavior. Another three hypotheses are:

H5: Outcome expectations are positively associated with attitude towards behavior.

H6: Outcome expectations are positively associated with subjective norm.

H7: Outcome expectations are positively associated with Perceived behavior control.

\section{Research Method}

\subsection{Measurement Development}

The first part of the questionnaire includes the basic information about the respondents such as gender, age, education, and work experience. The second section includes questions about attitude toward behavior, subjective norms, perceived behavioral control, social entrepreneurial intention, and outcome expectations. The author used seven-point Likert scales from "disagree strongly" to "agree strongly" for questions.

\subsubsection{Determinants of Ajzen'(1991) Theory of Planned Behavior}

Liñán and Chen (2009) developed a scale of TPB. This scale was used extensively in the study of intention to start a business. Thus, in this study, the authors use Liñán and Chen (2009)'s scale to measure attitude toward behavior, subjective norms, perceived behavioral control and social entrepreneurial intention.

\subsubsection{Outcome Expectations}

Although there are many studies on outcome expectations (Lanero et al., 2016; Shaw \& Carter, 2007; Tran et al., 2016), 
these studies have only been looking at the entrepreneurship (Jiang \& Wang, 2014; Manolova et al., 2008), research on social entrepreneurship is still very limited. In addition, studies on entrepreneurship are qualitative (Aileen Boluk \& Mottiar, 2014), and no research has produced a measure for outcome expectations in social entrepreneurship.

To develop a scale for outcome expectations, the author began with Schwartz (1992) theory of values. Values are considered high-level belief systems that are formed early in life and are shaped by personal experience. These values are not in the direct control of the individual and therefore cannot be denied or changed easily (Hemingway, 2005). Rokeach (2008) divides values into four components: cognitive, affective, behavioral and motivational. The cognitive component is the knowledge about what is desired. Affective sides of values are the emotions of an individual. Behavioral components derive from an intervening variable to create actions. Motivational components provide the means by which the ultimate goal is to be fulfilled. Social entrepreneurs are required to be committed to helping others and the community, rather than just making money (Thompson et al., 2000). The motives of social entrepreneurship can be linked to moral motivation, moral responsibility and altruistic reasons (Mair \& Marti, 2006).

In the entrepreneurship, the key components of value theory can be used to understand the role of values in motivation. Values are described as radial and sustainable standards (Schwartz, 1992, 1994) where entrepreneurs can reflect on the desirability and importance of their actions. In this sense, values can guide social entrepreneurs to recognize and pursue opportunities that are not merely economic or beneficial to their business, but also to others (Akar \& Dogan, 2018). Schwartz (1992) theory of values has been widely used and affirmed intercultural stability in more than 60 nations (Tartakovsky \& Schwartz, 2001). In Schwartz (1992) theory of values, there are four higher-order value types: self-enhancement, self-transcendence, openness to change and conservation. Self-enhancement refers to values belonging to power and accomplishment. Self-transcendence emphasizes concern for the welfare and interests of others. Openness to change emphasizes independent action, thought and feeling, and readiness for new experiences. Conservation emphasizes self-restriction, order and resistance to change. It encompasses security, conformity and tradition values, and opposes openness to change.

Based on four higher-order value types, the author developed 20 values to measure the impact of outcome expectations on the intention of becoming a social entrepreneur. These values were subsequently reduced to seven items. Finally, outcome expectations of social entrepreneurs are solving social problems, innovation, family tradition of social involvement, meaning in life, prestige and social recognition, competitive and favorite job and wealth (see Figure 2).

\subsection{Data Collection}

This study has targeted students. This choice is similar to previous studies (Hockerts, 2017; Kirby \& Ibrahim, 2011; Nga \& Shamuganathan, 2010; Tiwari et al., 2017; Zhang \& Cain, 2017). Survey data were collected from students at four universities in Binh Duong province in Vietnam Thu Dau Mot University, Eastern International University, Vietnamese-German University and Binh Duong University. These universities offer studies across a widen fields: medicine, law, and technical, natural, social and business sciences.

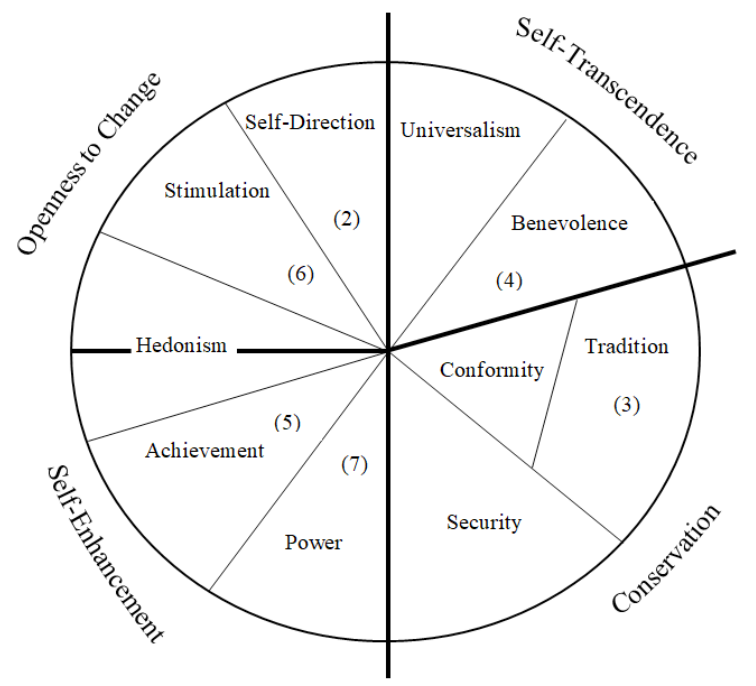

Note: (1) solving social problems, (2) innovation, (3) family tradition of social involvement, (4) meaning in life, (5) prestige and social recognition, (6) competitive and favorite job and (7) wealth.

Figure 2. Outcome expectation of social entrepreneurs in Schwartz's theoretical model (Schwartz 1994)

Table 1. Respondents demographics. $(n=251)$

\begin{tabular}{|l|c|c|}
\hline \multicolumn{2}{|c|}{ Categories } & Number of Observation \\
\hline \multirow{3}{*}{ Gender } & Male & $131(58 \%)$ \\
\cline { 2 - 3 } & Female & $120(42 \%)$ \\
\hline \multirow{4}{*}{$\begin{array}{l}\text { School } \\
\text { year }\end{array}$} & 1 & $15(5.9 \%)$ \\
\cline { 2 - 3 } & 2 & $80(31.8 \%)$ \\
\cline { 2 - 3 } & 3 & $67(26.69 \%)$ \\
\hline Total & 4 & $89(35.45 \%)$ \\
\hline
\end{tabular}


The author conducted a survey of 279 students to examine the relationship between outcome expectations and social entrepreneurial intention. The data collection was conducted through face-to-face structured interviews within a month. Two intensive training sessions were provided to three interviewers. 251 responses were collected. Sample demographics are depicted in Table 1; $58 \%$ of respondents were male and $42 \%$ were female.

\section{Results}

\subsection{Analysis of the Measurement Model}

Cronbach's Alpha was used to measure the reliability of construct (Bollen, 1989). A value of 0.60 is considered satisfactory for most studies (Hair Jr et al., 2016). Average Variance Extract (AVE) is used to measure convergence (Hair Jr et al., 2016). The AVE value of all elements above 0.5 indicates the validity of the elements in the model. In addition, composite reliability is used to evaluate the reliability of the model. A composite reliability (CR) index value above 0.70 indicates that the structures in the model are reliable. Cronbach's Alpha, AVE and CR are satisfactory and are presented in Table 2. According to Fornell and Larcker (1981), in any two constructs, square root of AVE should be greater than inter-construct correlations. The result in Table 3 satisfies criteria for discriminant validity

Table 2. Construct reliability and convergent validity

\begin{tabular}{|l|c|c|c|}
\hline \multicolumn{1}{|c|}{ Construct } & $\begin{array}{c}\text { Composite } \\
\text { reliability } \\
\text { (CR) }\end{array}$ & $\begin{array}{c}\text { Average } \\
\text { variance } \\
\text { extracted }\end{array}$ & $\begin{array}{c}\text { Cronbach's } \\
\text { alpha }\end{array}$ \\
\hline $\begin{array}{l}\text { Outcome } \\
\text { expectations }\end{array}$ & 0.863 & 0.516 & 0.862 \\
\hline $\begin{array}{l}\text { Attitude towards } \\
\text { behavior }\end{array}$ & 0.868 & 0.572 & 0.866 \\
\hline Subjective norms & 0.886 & 0.722 & 0.855 \\
\hline $\begin{array}{l}\text { Perceived } \\
\text { behavioral control }\end{array}$ & 0.903 & 0.614 & 0.897 \\
\hline $\begin{array}{l}\text { Social } \\
\text { entrepreneurial } \\
\text { intention }\end{array}$ & 0.902 & 0.608 & 0.898 \\
\hline
\end{tabular}

Table 3. Discriminant validity

\begin{tabular}{|l|c|c|c|c|c|}
\hline Construct & OE & ATB & SN & PBC & SEI \\
\hline OE & 0.718 & & & & \\
\hline ATB & 0.629 & 0.756 & & & \\
\hline SN & 0.577 & 0.684 & 0.849 & & \\
\hline PBC & 0.624 & 0.592 & 0.801 & 0.783 & \\
\hline SEI & 0.710 & 0.714 & 0.808 & 0.745 & 0.779 \\
\hline
\end{tabular}

Note: OE: Outcome expectations, ATB: Attitude towards behaviour, SN: Subjective norms, PBC: Perceived behavioural control, SEl: Social entrepreneurial intention

\subsection{Multicollinearity}

Multicollinearity exists when two or more of the predictors in a regression model are moderately or highly correlated. The variance inflation factor (VIF) is used to test multicollinearity. Hair Jr et al. (2016) suggested that the appropriate threshold of VIF was less than 10. The author used AMOS to test multicollinearity. From the results of the analysis, the VIF is less than 10 so the model does not occur multicollinearity.

\subsection{Analysis of the Structural Model}

The final results of the model are presented in Figure 3. The structural model also offers a good model fit, where a ratio of chi-square to the degree of freedom $(2 / \mathrm{df})$ is 2.382 , comparative fit index (CFI) is 0.95 , adjusted goodness offit index (AGFI) is 0.85, normed fit index (NFI) is 0.95, relative fit index (RFI) is 0.94 , and root mean square error of approximation (RMSEA) is reported at 0.075 (see Figure 3). The results of structural equation modeling indicate a good model fit (Hair Jr et al., 2016).

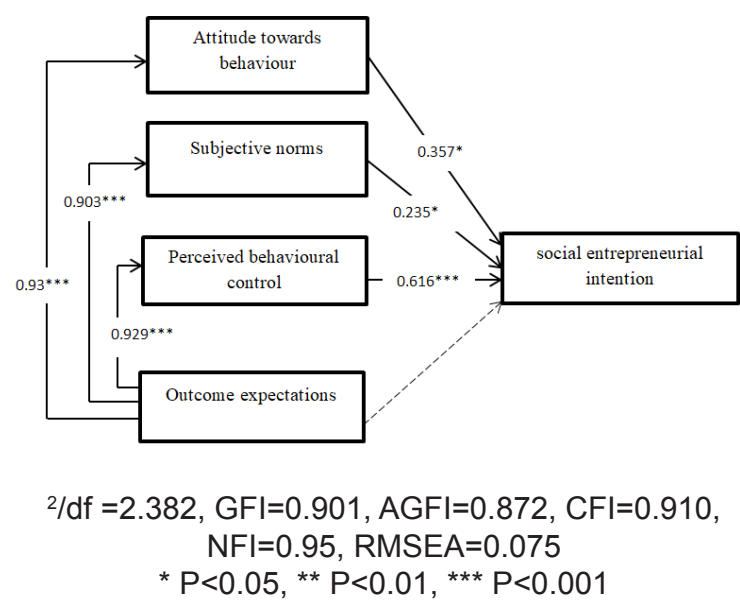

Figure 3. Results of SEM analysis

\subsection{Hypotheses Testing}

A structural equation modeling (SEM) approach was adopted in our data analysis. Figure 3 presents the results of the structural model with non-significant paths as dotted lines, and the standardized path coefficients between constructs. Social entrepreneurial intention in this study was jointly predicted by attitude towards behavior $(\beta=$ $0.357, \mathrm{p}<0.014)$, subjective norms $(\beta=0.235, \mathrm{p}<0.02)$ and perceived behavioral control $(\beta=0.616, p<0.001)$. As a result, Hypotheses 1, 2, and 3 were supported. Outcome expectations significantly influenced determinants of 
planned behavioral theory (attitude towards behaviour $(\beta=$ 0.93, $\mathrm{p}<0.001)$, subjective norms $(\beta=0.903, \mathrm{p}<0.001)$ and perceived behavioral control $(\beta=0.929, \mathrm{p}<0.001)$. Accordingly, Hypotheses 5, 6 and 7 was supported. Outcome expectations $(\beta=0.903, \mathrm{p}<0.001)$ did not significantly affect social entrepreneurial intention. Hence, Hypothesis 4 was not supported.

\section{Discussion}

\subsection{Outcome Expectations Scale}

Based on four higher-order value types of Schwartz (1992) theory of values, the author developed seven items to measure outcome expectations: solving social problems, innovation, family tradition of social involvement, meaning in life, prestige and social recognition, competitive and favorite job and wealth.

Solving social problems. All interviewed social entrepreneurs believed that solving social problems and working toward sustainable development are motivational to them. These issues are divided into two groups: human issues and environmental issues. Some social entrepreneurs said they want to tackle the environmental issues concerning chemicals or resource issues, for example. Some entrepreneurs stated helping others to be a motivational factor to them.

Wealth. All of the social enterprises interviewed in this research are non-profit social organizations and for-profit social organizations with limited distribution of profit. The main goal of social enterprises is to solve social problems, but that does not mean that social enterprises are charity organizations. They expect profit from business activities of their social enterprises. The more profits they have, the more opportunities to help the government deal with social issues.

Competitive and challenging job. Social entrepreneurship is a difficult and challenging job. Therefore, some entrepreneurs believe that the challenge has driven them into the social entrepreneurship field to satisfy themselves.

Meaning in life. All interviewees stated that their motivation was derived from the desire to do a meaningful job instead of work in general It goes beyond helping others to making a substantial possibly sustainable change. They feel like they are generating good and enabling a positive change. Many of the interviewed entrepreneurs mentioned that the positive feedback they receive also helps them stay motivated.

Family tradition of social involvement. Some social entrepreneurs continue their family traditions and they want their children to continue working in the social business to help others. They argue that this is a good family tradition to be promoted.
Prestige and social recognition. Some entrepreneurs say they also want to be recognized by society as their contribution. These will create credibility and social recognition to help promote their social business better.

Innovation. Although the interviewed social entrepreneurs are in various industries, most of them can be seen as pioneer in their own field. Some entrepreneurs developed new methods to conduct business in seemingly traditional areas, some created completely new businesses that did not exist before or they replaced the old methods by the new methods. Most of them are creators and they admit innovation motivated them to become social entrepreneurs.

\subsection{Outcome Expectations and Social Entrepreneurial Intention}

In entrepreneurial intention studies, attitude toward behavior, subjective norms, perceived behavioral control and outcome expectations are widely used factors to predict intention to star business (Jiang \& Wang, 2014; Manolova et al., 2008; Tran et al., 2016). However, the interaction between these factors is still poorly studied. This study combines outcome expectations in SCCT into TPB to examine the impact of outcome expectations on social entrepreneurship and three determinants of TPB. Research results show that outcome expectations indirectly affect entrepreneurial intention through the three determinants of TPB

First, the results show no direct link between outcome expectations and social entrepreneurial intention. It suggests that outcome expectations may be flexible factor. Individual outcome expectations can shift to motivations when recognizing the obvious opportunities to start a social business as well as the support from family and government. For example, an individual recognizes the outcome expectations of becoming a social entrepreneur. However, the establishment of social enterprises is still new and difficult; starting a social business will depend on the support of the family and support policies of the government. Therefore, it would be difficult to consider outcome expectations as a fixed factor. Identifying intermediaries will be more effective when considering the impact of outcome expectations on social entrepreneurial intention. This study has identified these mediating factors to include attitude toward behavior, subjective norms and perceived behavioral control.

\section{Implications}

\subsection{Managerial Implication}

This study suggests some management implications for increasing social entrepreneurial intention. First, the results of this study can help better understand what can make social entrepreneurs more attractive to larger audiences. 
Secondly, the motivations of social entrepreneurs are quite different from those of commercial entrepreneurs. Therefore, the university needs to build extra-curricular programs combining volunteer activities and knowledge related to social entrepreneurship to promote social entrepreneur motivational values. Third, motivational values help to distinguish between types of entrepreneurs, so that policymakers can develop incentive policies that maintain the motivation for social entrepreneurs.

\subsection{Theoretical Implications}

First, this study attempts to integrate TPB and SCCT and apply it in measuring the impact of the outcome expectations on social entrepreneurial intention. The results of this study show that outcome expectations impact all three determinants of Ajzen's (1991) theory of planned behavior in forming social entrepreneurial intention. Therefore, the proposed model contributes importantly to the emerging literature on entrepreneurial intention, particularly to social entrepreneurial intention.

Second, this is the first study to build a scale for outcome expectations. Based on four higher-order value types of Schwartz (1992) theory of values, we developed seven items to measure outcome expectations: solving social problems, innovation, family tradition of social involvement, meaning in life, prestige and social recognition, competitive and favorite job and wealth.

Third, this study is also the first quantitative study to measure the impact of outcome expectations on social entrepreneurial intention. The empirical result shows that the outcomes impact only through three determinants of Ajzen's (1991) theory of planned behavior and do not have significant impact to social entrepreneurial intention. It suggests that outcome expectations may be flexible factor. Individual outcome expectations can shift to motivations when facing favorable conditions such as family support, government support, etc.

\section{Limitations and Future Research}

There are several issues that could be considered in the light of future research. We build a scale for outcome expectations without distinction between industries where the social entrepreneurs operate. Future studies should use different samples in different industries and countries to examine and develop scales for outcome expectations. Secondly, this study did not investigate the educational background or demographic factors to the outcomes expectations in forming the social entrepreneurial intention. Future studies may incorporate educational background or demographic factors into the proposed model.

\section{Conclusions}

This paper aims to explain social entrepreneurial intention through outcome expectations. The proposed model incorporates outcome expectations of SCCT and TPB. The results suggest that the proposed model adequately explains the relationship between outcome expectations and social entrepreneurial intentions. Despite several limitations, the article has suggested interesting results about outcome expectations of social entrepreneurs: outcome expectations may be flexible factors that do not directly affect social entrepreneurial intention and indirectly affect social entrepreneurial intention through attitude toward behavior, subjective norms and perceived behavioral control.

\section{References}

Aileen Boluk, K., \& Mottiar, Z. (2014). Motivations of social entrepreneurs: Blurring the social contribution and profits dichotomy. Social Enterprise Journal, 10(1), 53-68.

Ajzen, I. (1991). The theory of planned behavior. Organizational Behavior and Human Decision Processes, 50(2), 179-211.

Ajzen, I. (2002). Perceived behavioral control, self-efficacy, locus of control, and the theory of planned behavior. Journal of Applied Social Psychology, 32(4), 665-683.

Akar, H., \& Dogan, Y. B. (2018). The Role of Personal Values in Social Entrepreneurship. Universal Journal of Educational Research, 6(1), 83-90.

Arenius, P., \& Minniti, M. (2005). Perceptual variables and nascent entrepreneurship. Small Business Economics, 24(3), 233-247.

Armitage, C. J., \& Conner, M. (2001). Efficacy of the theory of planned behaviour: A meta-analytic review. British Journal of Social Psychology, 40(4), 471-499.

Austin, J., Stevenson, H., \& Wei-Skillern, J. (2006). Social and commercial entrepreneurship: same, different, or both? Entrepreneurship Theory and Practice, 30(1), 1-22.

Bandura, A. (1982). Self-efficacy mechanism in human agency. American Psychologist, 37(2), 122-147.

Bandura, A. (1991). Social cognitive theory of self-regulation. Organizational Behavior and Human Decision Processes, 50(2), 248-287.

Bandura, A. (1993). Perceived self-efficacy in cognitive development and functioning. Educational Psychologist, 28(2), 117-148.

Bird, B. (1988). Implementing entrepreneurial ideas: The case for intention. Academy of Management Review, 13(3), 442-453.

Bollen, K. A. (1989). A new incremental fit index for general structural equation models. Sociological Methods \& Research, 17(3), 303-316. 
Do Paco, A., Ferreira, J., Raposo, M., Rodrigues, R. G., \& Dinis, A. (2011). Entrepreneurial intention among secondary students: findings from Portugal. International Journal of Entrepreneurship and Small Business, 13(1), 92-106.

Fornell, C., \& Larcker, D. F. (1981). Evaluating structural equation models with unobservable variables and measurement error. Journal of Marketing Research, 18(1), 39-50.

Germak, A. J., \& Robinson, J. A. (2014). Exploring the motivation of nascent social entrepreneurs. Journal of Social Entrepreneurship, 5(1), 5-21.

Grünhagen, M., \& Volkmann, C. K. (2014). Antecedents of academics' entrepreneurial intentions-developing a peopleoriented model for university entrepreneurship. International Journal of Entrepreneurial Venturing, 6(2), 179-200.

Hair Jr, J. F., Hult, G. T. M., Ringle, C., \& Sarstedt, M. (2016). A primer on partial least squares structural equation modeling (PLS-SEM). Los Angeles, California: Sage publications.

Hemingway, C. A. (2005). Personal values as a catalyst for corporate social entrepreneurship. Journal of Business Ethics, 60(3), 233-249.

Hockerts, K. (2017). Determinants of social entrepreneurial intentions. Entrepreneurship Theory and Practice, 41(1), 105130.

Iakovleva, T., \& Solesvik, M. Z. (2014). Entrepreneurial intentions in post-Soviet economies. International Journal of Entrepreneurship and Small Business, 21(1), 79-100.

Ip, C. Y., Wu, S.-C., Liu, H.-C., \& Liang, C. (2017). Revisiting the antecedents of social entrepreneurial intentions in Hong Kong. International Journal of Educational Psychology, 6(3), 301323.

Jiang, Z., \& Wang, Z. (2014). Entrepreneurial intention and outcome expectancy: Evidence from South Korea and China. Contemporary Management Research, 10(3), 251.

Kahneman, D. (2003). A perspective on judgment and choice: mapping bounded rationality. American Psychologist, 58(9), 697-720.

Kirby, D. A., \& Ibrahim, N. (2011). The case for (social) entrepreneurship education in Egyptian universities. Education + Training, 53(5), 403-415.

Koçoğlu, M., \& Hassan, M. U. (2013). Assessing entrepreneurial intentions of university Students: A comparative study of two different Cultures: Turkey and Pakistani. European Journal of Business and Management, 5(13), 243-252.

Krueger, N. F., \& Brazeal, D. V. (1994). Entrepreneurial potential and potential entrepreneurs. Entrepreneurship Theory and Practice, 18(3), 91-104.

Krueger, N. F., Reilly, M. D., \& Carsrud, A. L. (2000). Competing models of entrepreneurial intentions. Journal of Business Venturing, 15(5), 411-432.

Lanero, A., Vázquez, J.-L., \& Aza, C. L. (2016). Social cognitive determinants of entrepreneurial career choice in university students. International Small Business Journal, 34(8), 10531075.

Lent, R. W., \& Brown, S. D. (2008). Social cognitive career theory and subjective well-being in the context of work. Journal of Career Assessment, 16(1), 6-21.

Lent, R. W., Brown, S. D., \& Hackett, G. (1994). Toward a unifying social cognitive theory of career and academic interest, choice, and performance. Journal of Vocational Behavior, 45(1), 79122.

Lent, R. W., Brown, S. D., \& Hackett, G. (2000). Contextual supports and barriers to career choice: A social cognitive analysis. Journal of Counseling Psychology, 47(1), 36-49.

Liguori, Bendickson, J. S., \& McDowell, W. C. (2018). Revisiting entrepreneurial intentions: a social cognitive career theory approach. International Entrepreneurship and Management Journal, 14(1), 67-78.

Liñán, F., \& Chen, Y. W. (2009). Development and Cross-Cultural application of a specific instrument to measure entrepreneurial intentions. Entrepreneurship Theory and Practice, 33(3), 593617.

Lu, H., \& Wang, J. (2018). Entrepreneurial intention of two patterns of planned behaviour and alertness: empirical evidence in China. Journal of Asian Finance Economics and Business, 5(2), 63-72. https://doi.org/10.13106/jafeb.2018.vol5.no2.63

Mair, \& Marti, I. (2006). Social entrepreneurship research: A source of explanation, prediction, and delight. Journal of World Business, 41(1), 36-44.

Manolova, T. S., Brush, C. G., \& Edelman, L. F. (2008). What do women entrepreneurs want? Strategic Change, 17(3-4), 69-82.

Moriano, J. A., Gorgievski, M., Laguna, M., Stephan, U., \& Zarafshani, K. (2012). A cross-cultural approach to understanding entrepreneurial intention. Journal of Career Development, 39(2), 162-185.

Nga, J. K. H., \& Shamuganathan, G. (2010). The influence of personality traits and demographic factors on social entrepreneurship start up intentions. Journal of Business Ethics, 95(2), 259-282.

Phan, L. T. (2018). The Relationship between Perceived Access to Finance and Social Entrepreneurship Intentions among University Students in Vietnam. Journal of Asian Finance Economics and Business, 5(1), 63-72. http://dx.doi. org/10.13106/jafeb.2018.vol5.no1.63

Rokeach, M. (2008). Understanding human values. New York: Simon and Schuster.

Schwartz, S. H. (1992). Universals in the content and structure of values: Theoretical advances and empirical tests in 20 countries. Advances in Experimental Social Psychology, 25(1), 1-65.

Schwartz, S. H. (1994). Are there universal aspects in the structure and contents of human values? Journal of Social Issues, 50(4), $19-45$. 
Seelos, C. (2014). Theorising and strategising with models: generative models of social enterprises. International Journal of Entrepreneurial Venturing, 6(1), 6-21.

Shaw, E., \& Carter, S. (2007). Social entrepreneurship: Theoretical antecedents and empirical analysis of entrepreneurial processes and outcomes. Journal of Small Business and Enterprise Development, 14(3), 418-434.

Tartakovsky, E., \& Schwartz, S. H. (2001). Motivation for emigration, values, wellbeing, and identification among young Russian Jews. International Journal of Psychology, 36(2), 8899.

Thompson, J., Alvy, G., \& Lees, A. (2000). Social entrepreneurship-a new look at the people and the potential. Management Decision, 38(5), 328-338.

Tiwari, P., Bhat, A. K., \& Tikoria, J. (2017). Predictors of social entrepreneurial intention: an empirical study. South Asian Journal of Business Studies, 6(1), 53-79.

Tran, A. T., Tran, A. T., Von Korflesch, H., \& Von Korflesch, H. (2016). A conceptual model of social entrepreneurial intention based on the social cognitive career theory. Asia Pacific Journal of Innovation and Entrepreneurship, 10(1), 17-38.

Tran, V. D. (2020). Assessing the Effects of Service Quality, Experience Value, Relationship Quality on Behavioral Intentions.
Journal of Asian Finance, Economics and Business, 7(3), 167175. https://doi.org/10.13106/jafeb.2020.vol7.no3.167

Vikstrom, A., \& Westerberg, M. (2010). Success with succession: an empirical study of small Swedish family firms. International Journal of Entrepreneurship and Small Business, 11(3), 223241.

Wood, R., \& Bandura, A. (1989). Impact of conceptions of ability on self-regulatory mechanisms and complex decision making. Journal of Personality and Social Psychology, 56(3), 407.

Zahra, S. A., Gedajlovic, E., Neubaum, D. O., \& Shulman, J. M. (2009). A typology of social entrepreneurs: Motives, search processes and ethical challenges. Journal of Business Venturing, 24(5), 519-532.

Zainuddin, M. N., \& Ismail, H. (2011). Push and pull factor in an entry into an employment route: a study of nurtured entrepreneurship students. International Journal of Entrepreneurship and Small Business, 13(4), 469-498.

Zhang, P., \& Cain, K. W. (2017). Reassessing the link between risk aversion and entrepreneurial intention: The mediating role of the determinants of planned behavior. International Journal of Entrepreneurial Behavior \& Research, 23(5), 793-811.

Zhao, H., Seibert, S. E., \& Hills, G. E. (2005). The mediating role of self-efficacy in the development of entrepreneurial intentions. Journal of Applied Psychology, 90(6), 1265-1272. 